\title{
Competitiveness Indicators of Catering Business Entities: The Case of Russia
}

\author{
Submitted 02/02/19, 1st revision 26/02/19, 2nd rervision 24/04/19, accepted 06/06/19 \\ T.A. Dzhum ${ }^{1}$, M.V. Ksenz ${ }^{2}$, L.S. Mikhailova ${ }^{3}$, S.S. Malkhasjan ${ }^{4}$
}

\begin{abstract}
:
Purpose: The article analyzes the existing marketing strategies in catering and define their influence on the competitiveness level of catering business entities in Russia.

Design/Methodology/Approach: This article is dedicated to generalizing papers on the problems of catering marketing strategy formation. The object of the research is marketing strategies in catering and their influence on the competitiveness level of the entities.

Findings: The novelty of the research is an algorithm of evaluation of the competitiveness level and marketing strategy adjustment of operating catering business entities based on the analysis of their major performance indicators. The algorithm with its system of certain indicators allows defining the competitiveness level, selecting and adjusting marketing strategies and sub-strategies, and, thus, enhancing the effectiveness of catering business entity performance.

Practical implications: Flexibility and adaptiveness of this system entails that any catering business entity can select priority indicators from it and then calculate them to adjust marketing strategies and sub-strategies based on data obtained in the meantime.

Originality/Value: The value lies in the disclosure of industry specifics of strategic marketing management in a definite economic activity considering essential strategic and operational factors which determine ultimate economic effectiveness of target marketing exposures.
\end{abstract}

Keywords: Competition, consumer expectations, solvency, methods of competitiveness assessment, marketing strategies, consumer value of catering services, quality.

JEL Codes: D10, D11, D30, D39.

Paper Type: Research article in Special Issue dedicated to Russian Economy.

Section 8: Business and Economic Issues.

${ }^{1}$ PhD in Engineering, Associate Professor of the Department of Trade and Catering, Plekhanov Russian University of Economics, Krasnodar Affiliate, tatalex7@mail.ru

${ }^{2} P h D$ in Engineering, Associate Professor of the Department of Trade and Catering, Plekhanov Russian University of Economics, Krasnodar Affiliate, mksenz77@mail.ru

${ }^{3} \mathrm{PhD}$ in Economics, Professor of the Department of Economics and Management, Plekhanov Russian University of Economics, Krasnodar Affiliate, lysine82-82@ mail.ru

${ }^{4} \mathrm{PhD}$ in Economics, Professor of the Department of Public and Corporate Governance, Academy of Marketing and Socio-Information Technologies, mcc84@mail.ru 


\section{Introduction}

The sphere of catering is a set of entities of different organizational and legal forms of ownership, types, specializations united by the same requirements and approaches to the organization of production and consumer servicing. Types of catering (public catering) business entities are indicated in GOST 30389-2013 "Public catering services. Public catering entities. Classifications and general requirements". The definition of the type includes the specifics of product, price, marketing policy, marketing promotion and products and services distribution considering consumers' target segment. A restaurant viewed and demonstrated as a whole set of approaches to organization of activity intrinsic to this sector and being in the highest demand in the consumer environment is considered among catering business entities. Since the consumer environment is heterogeneous, restaurant owners are elaborating different proposals for various segments of the restaurant.

\section{Monitoring of Competitive Performance of Catering Facilities}

Russian catering business is young enough, and it cannot be considered fullyfledged. Notwithstanding competition in it has its peculiarities:

- some entities except finest restaurants can compete on a municipal scale in the market segment event management, servicing business meetings, tourists, etc.;

- publicly available entities functioning, as a rule, in the context of perfect competition, which is characteristic of: many public catering facilities of different types selling a definite (specialized) product range in the homogeneous market segment satisfying diverse needs of population in terms of nutrition;

- a specific nature of competition related to public catering facilities' fulfillment of production functions, sales of products and consumption. On the one hand, it requires considering production capacities of a definite volume of output. On the other hand, it requires considering consumer expectations, their solvency.

The current state of competition in the restaurant market in the capital and large cities of Russia is characterized mainly by the development of non-price competition between individual restaurants of the same price niche. Whereas there is a price factor in competition prevailing in the provinces and the Russian hinterland, on the contrary. The reason for this is the very low-income level of most of the population, the unpretentiousness to the quality of restaurant service.

However, more importance is being increasingly given to the tools for non-price competition in separate segments of the market on selling products and services targeted at consumers with high- and medium-income levels. Currently, many authors in the scientific literature cover issues of building the methodology of economic analysis, including in relation to methods for assessing competitiveness and research of business processes of enterprises in the catering business (Blanchard et al., 2014; Dzhum and Zayko, 2015; Mill, 2011; Friedman, 2013; Chudnovskiy 
and Zhukova et al., 2014).

\section{The Approach to the Implementation of Monitoring Procedures in Marketing and Operating Activities of Public Catering Entities}

Given that marketing is based on customer satisfaction, the most appropriate definition that reflects the marketing aspects of an enterprise is the definition of competitiveness based on the ability of an enterprise to meet consumer interests (Diyanova and Dzhum, 2018; Dzhum and Zadneprovskiy, 2018; Dzhum and Ksenz, 2018). The competitiveness of catering business entities is a certain state characterized by a certain level of indicators that form the competitive advantages of goods, services and the enterprise itself, ensuring more efficient satisfaction of consumer expectations facilitating efficient activity in a competitive market. There are the following methods for assessing competitiveness:

- a method of calculating a group parametric index of competitiveness (the calculation of a hard-parametric index, a soft parametric index and a composite index);

- a method of calculating an integral index of competitiveness.

A method for calculating the integral indicator of competitiveness proposed in qualimetry serves as a universal integrated indicator of competitiveness. It is based on the method of expert assessments. The correctness of the results of the assessment of competitiveness will depend on the system of estimated indicators. Thus, the core problem in the methodology for assessing competitiveness is a scientifically based choice of a nomenclature of indicators. In this regard the essence of the value proposition of catering services, considering the basic concepts: "service", "servicing" and "service conditions", should be considered to identify indicators for assessing competitiveness. A service is the result of the interaction between the contractor and the service consumer, that is, the service is considered as the contractor's activity in the process of contacting the consumer, and the terms of service are a combination of factors.

Thus, based on the above, the system of indicators for assessing competitiveness should include indicators related to the service and the level of service. The existing systems of competitiveness indicators and their adaptability to the catering services market are viewed below. Based on the analysis of existing indicators of competitiveness assessment, a classification scheme has been developed. The scheme has several levels of specification, according to which the competitiveness of products (goods and services) consists of the following elements:

\section{Price competitiveness of products:}

1.1. The ratio of the price level with the prices of major competitors.

1.2. The effectiveness of the price differentiation system depending on the ratio of supply and demand, as well as prices of competitors. 
1.3. Attractiveness of the discount system for consumers.

2. Product quality:

2.1. Technical and functional characteristics of products.

2.2. Additional benefits.

2.3. Brand credibility.

3. Competitiveness of sales (marketing), advertising and service system:

3.1. Convenience of the sales system for consumers.

3.2. Advertising effectiveness.

3.3. Convenience and credibility of service systems.

3.4. Effectiveness of the public relations system.

A relatively small number of indicators proposed by the authors related to the fact that the more detailed the initial concept is, the less the number of objects applying this scheme will be. Considering that services are a specific product due to their socio-economic nature, it is possible to provide those indicators that will be acceptable for assessing the competitiveness of catering business entities: service level indicators, technological level indicators, commercial indicators. With regard to the system of indicators for assessing the competitiveness of an enterprise, the indicators proposed by Fatkhutdinov (2014) and supplemented by the authors in accordance with the specifics of the activities of catering business entities are the most appropriate and adaptable to the specifics of catering business.

Table 1. Formulas for calculating the system of indicators to assess the competitiveness of catering business entities

\begin{tabular}{|c|c|}
\hline Indicator & Calculation of an indicator / interpretation \\
\hline Appointment rates & $\begin{array}{l}\text { Evaluated based on expert assessment depending on } \\
\text { restaurant class }\end{array}$ \\
\hline \multicolumn{2}{|l|}{$\begin{array}{l}\text { Reliability } \quad \text { indicators, } \\
\text { including: }\end{array}$} \\
\hline standard operation time & $\begin{array}{l}\text { taken from the documents on the technological } \\
\text { equipment }\end{array}$ \\
\hline suitability ratio & $\begin{array}{l}\mathrm{Rs}=\mathrm{Vd} / \mathrm{Vb} \\
\text { where } \mathrm{Rs}-\text { suitability ratio; } \\
\mathrm{Vd}-\text { depreciated value; } \\
\mathrm{Vb}-\text { book value }\end{array}$ \\
\hline availability ratio & $\begin{array}{l}\text { Ra }=\text { Nuo / No, } \\
\text { where Ra - availability ratio; } \\
\text { Nuo - number of unfulfilled orders; } \\
\text { No - number of orders }\end{array}$ \\
\hline storage ratio & $\begin{array}{l}\text { Rs = OTo / OTs, } \\
\text { where Rs - storage ratio; } \\
\text { OTs - standard operation time; } \\
\text { OTo- observed operation time }\end{array}$ \\
\hline Aesthetics rates & Expert assessment \\
\hline
\end{tabular}




\begin{tabular}{|c|c|}
\hline $\begin{array}{l}\text { Matching rates of raw materials } \\
\text { usage }\end{array}$ & $\begin{array}{l}\text { The quantitative assessment is calculated as follows: } \\
\text { Re = Uf/Un, } \\
\text { where } R e \text { - efficiency ratio, } \\
\text { Uf - factual raw materials usage for } 100 \text { portions or } 10 \\
\mathrm{~kg} \text {; } \\
\text { Un - raw materials usage norm for } 100 \text { portions or } 10 \mathrm{~kg}\end{array}$ \\
\hline $\begin{array}{l}\text { Strategic marketing costs, } \% \text { of } \\
\text { total income }\end{array}$ & Quantitative assessment \\
\hline Service costs & Quantitative assessment \\
\hline $\begin{array}{l}\text { Costs of equipment repair and } \\
\text { maintenance for the standard } \\
\text { operation time }\end{array}$ & Quantitative assessment \\
\hline Image of an enterprise & Survey, expert assessment \\
\hline $\begin{array}{l}\text { Legal reliability of an } \\
\text { enterprise }\end{array}$ & Survey \\
\hline $\begin{array}{l}\text { Financial reliability } \\
\text { (sustainability) of an enterprise }\end{array}$ & $\begin{array}{l}\text { A system of financial management indicators can be } \\
\text { used }\end{array}$ \\
\hline Quality of information & Expert assessment \\
\hline Quality of serving & Consumer survey \\
\hline Quality of service & Consumer survey, expert assessment \\
\hline $\begin{array}{l}\text { The average consumption rate } \\
\text { of raw materials in dishes }\end{array}$ & $\begin{array}{l}\mathrm{N}=\sum\left(\mathrm{N}_{1} \times \mathrm{D}_{1}\right) / \sum \mathrm{D}_{1}, \\
\text { where } \mathrm{N}_{1}-\text { individual norms of raw materials usage for } \\
\text { each dish unit; } \\
\mathrm{D}_{1}-\text { number of definite dishes; } \\
\sum \mathrm{D}_{1}-\text { total number of dishes }\end{array}$ \\
\hline $\begin{array}{l}\text { Significance of the market of } \\
\text { presented services }\end{array}$ & Expert assessment \\
\hline Market volume & Quantitative assessment \\
\hline $\begin{array}{l}\text { Number of subjects and their } \\
\text { market share }\end{array}$ & $\begin{array}{l}\text { Quantitative assessment } \\
\mathrm{Sm}=\mathrm{Rn} / \mathrm{Rr} \\
\text { where } \mathrm{Sm}-\text { market share } \\
\mathrm{Sn}-\text { sales of enterprise } \mathrm{N} \text {; } \\
\text { Sm }- \text { sales on the market }\end{array}$ \\
\hline Barriers to the market entry & Expert assessment \\
\hline
\end{tabular}

This system of indicators is dominated by qualitative indicators obtained based on expert assessments. It is predetermined by the fact that several indicators necessary for assessing competitiveness are not systematically measured, and, accordingly, are not tracked over time. Flexibility and adaptability of this system lies in the fact that any catering business entity can select priority indicators for itself from this system and subsequently calculate them. Then, it can adjust marketing strategies and substrategies based on the data obtained. The specifics of the activities of catering business entities is determined by the combination of those business processes they conduct, considering the production and trading process characteristic of these institutions. In many modern catering entities, production and customer service is the only area in which there is quantitative data on business processes. It is necessary to supplement these data with the results of special studies of other 
business processes characterized by high costs, and to provide the manager with background information.

\section{Conclusion}

The modern market of catering services is characterized by a very rapid degree of development and a high level of competition. The catering services market is marked by a significant increase in quantitative indicators and an improvement in quality characteristics. In connection with the existing problems, attention should be paid to the development of appropriate strategies. The strategies should envisage such possible ways to solve the arising problems as to provide increased control over the quality and safety of products together with authorized federal authorities and the improvement of technical equipment to create more favorable food storage conditions and its cooking. Although enterprises of various formats are represented in the catering services market, nevertheless, the need for catering points is satisfied neither in the Russian Federation as a whole nor in the regions. In this regard, the sphere of catering business relates to an actively developing sector of the economy.

\section{References:}

Blanchard, K., Billard, D., Finch, F. 2014. How to gain loyalty of clients in the field of services. Moscow, EKSMO, 175.

Chudnovskiy, A.D., Zhukova, M.A., Belozerova, Yu.M., Knyshova, E.N. 2014. Hospitality industry: fundamentals of organization and management. Moscow, Publishing House "Forum", INFRA-M, 400.

Diyanova, S.N., Dzhum, T.A. 2018. Innovative marketing technologies as a tool for the implementation of customer focus in the restaurant business. Monograph, Plekhanov Russian University of Economics, Krasnodar Affiliate, Krasnodar, 104.

Dzhum, T.A., Ksenz, M.V. 2018. Creating a new business of various formats in the Russian market of food services. The electronic collection of materials of the III International scientifically and practical conference "Innovation in the food industry and service" dedicated to the $100^{\text {th }}$ anniversary of the Kuban State Technological University, October, Krasnodar, KubSTU Publishing House, 76-81.

Dzhum, T.A., Zadneprovskaya, E.L. 2018. Problems and barriers in the public catering sphere and major directions of its development. The electronic collection of materials of the III International scientifically and practical conference "Innovation in the food industry and service" dedicated to the $100^{\text {th }}$ anniversary of the Kuban State Technological University, October, Krasnodar, KubSTU Publishing House, 72-81.

Dzhum, T.A., Zayko, G.M. 2015. Modern forms of service in the restaurant business. Moscow, Magistr, INFRA-M, 528.

Fatkhutdinov, R.A. 2014. Innovation Management. The Standard of the third generation, Saint Petersburg, Piter, 448.

Friedman, A.M. 2013. Economics of catering. Moscow, Dashkov and K. publishing, 464.

Mill, R.K. 2011. Restaurant management. Moscow, Publishing House "UNITY-DANA", 158. 